Pokas B, Semenenko V, lefanova V. Theoretical substantiation of the assessment system of the physical fitness level of student youth of institutions of professional pre-higher education. Theory and Methods of Physical education and sports. 2020; 1 : 87-92

DOI: $10.32652 /$ tmfvs.2020.1.87-92
Покас Б, Семененко В, Єфанова В. Теоретичне обґрунтування системи оцінювання рівня фрізичної підготовленості студентської молоді закладів фахової передвищої освіти.

Теорія і методика фрізичного виховання

і спорту. 2020; 1: 87-92

DOI: $10.32652 /$ tmfvs.2020.1.87-92

\title{
ТЕОРЕТИЧНЕ ОБГРУНТУВАННЯ СИСТЕМИ ОЦНЮВАННЯ РІВНЯ ФІЗИЧНОЇ ПІДГОТОВЛЕНОСТІ СТУДЕНТСЬКОЇ МОЛОДІ ЗАКЛАДІВ ФАХОВОЇ ПЕРЕДВИЩОЇ ОСВІТИ
}

\section{Богдан Покас, В’ячеслав Семененко, Валентина Сфанова}

Національний університет фізичного виховання і спорту України, Київ, Україна

\begin{abstract}
Анотація. Розглянуто підходи до оцінювання рівня фрізичної підготовленості студентської молоді в процесі фрізичного виховання закладів фахової передвищої освіти. Мета. Визначити сучасні підходи до оцінювання рівня фрізичної підготовленості як обов'язкової складової освітнього процесу студентської молоді закладів фахової передвищої освіти. Методи. Теоретичний аналіз і узагальнення даних літературних джерел, передового педагогічного та наукового досвіду. Результати. На сьогодні жоден документ чи нормативно-правовий акт, який регламентує процес фрізичного виховання в закладах фрахової передвищої освіти, не передбачає диференціації в оцінюванні рівня фрізичної підготовленості студентської молоді залежно від їхніх морфологічних показників, рівня фрізичного здоров'я тощо. Аналіз даних науково-методичної літератури дозволив виявити, що контрольні нормативи, передбачені в процесі фрізичного виховання різних вікових груп, недостатньо обґрунто-

вані. Вони не відповідають віковим, руховим та функціональним особливостям дітей та молоді.

Для вирішення відповідних завдань, які стоять перед підготовкою майбутніх фрахівців, слід розробляти диференційований підхід до оцінювання фрізичної підготовленості з методично правильною побудовою процесу фрізичного виховання молоді з використанням адекватних форм організації та методів контролю.

Серед напрямів діяльності викладача повинні бути враховані не тільки результати тестів фрізичної підготовленості, а й ставлення студентів до цього виду діяльності, рівень сформованої мотивації, потреба у цих заняттях. Сучасні умови життєдіяльності та розвитку суспільства вимагають врахування нових критеріїв оцінювання рівня фрізичної підготовленості, що дозволить удосконалити процес фрізичного виховання, а також сприятиме зміцненню рівня фрізичного здоров'я, покращенню фрізичного розвитку та фізичної підготовленості з урахуванням вимог майбутньої професійної діяльності студентської молоді закладів фахової передвищої освіти. Аналіз науково-методичної літератури, присвяченої підходам до оцінювання рівня фізичної підготовленості студентської молоді закладів фрахової передвищої освіти, виявив, що питання їх диференціації за останні роки не втратили своєї актуальності.
\end{abstract}

Ключові слова: заклад фрахової передвищої освіти, студентська молодь, фрізична підготовленість, диференційований підхід.

\section{Bohdan Pokas, Viacheslav Semenenko, Valentyna Iefanova THEORETICAL SUBSTANTIATION OF THE ASSESSMENT SYSTEM OF THE PHYSICAL FITNESS LEVEL OF STUDENT YOUTH OF INSTITUTIONS OF PROFESSIONAL PRE-HIGHER EDUCATION}

\begin{abstract}
Approaches to assessing physical fitness level of student youth in the process of physical education of professional pre-higher education institutions are considered. Objective. Identify modern approaches to assessing the level of physical fitness as a mandatory component of the educational process of student youth of professional pre-higher education institutions. Methods. Theoretical analysis and generalization of data from literary sources, advanced pedagogical and scientific experience. Results. To date, no document or normative legal act regulating the process of physical education in vocational pre-higher education institutions envisages differentiation in assessing the level of physical fitness of student youth depending on their morphological indices, level of physical health, etc. Analysis of scientific and methodological literature data revealed that the control standards provided in the process of physical education of different age groups are not sufficiently substantiated and do not correspond to the age, motor and functional characteristics of children and youth.

To solve the relevant tasks facing the training of future professionals, it is necessary to develop a differentiated approach to assessing physical fitness with methodically correct design of physical education process for young people using adequate forms of organization and methods of control.

Among the teacher activities not only the results of physical fitness tests, but the attitude of students to this type of activity, the level of motivation, the need for these sessions should be taken into account.

Modern living conditions and development of society require accounting for new criteria for assessing the level of physical fitness, which will improve the process of physical education, as well as strengthen physical health,
\end{abstract}


improve physical development and physical fitness with account for the requirements of future professional activity of students of professional pre-higher education.

Analysis of scientific and methodological literature on approaches to assessing the level of physical fitness of student youth of institutions of professional pre-higher education revealed that the issue of their differentiation in recent years has not lost its relevance.

Keywords: institution of professional pre-higher education, student youth, physical fitness, differentiated approach.

Вступ. Освітній процес у сфері фахової передвищої освіти - це інтелектуальна, творча діяльність, що проводиться у закладі фахової передвищої освіти та спрямована на передачу, засвоєння, примноження i використання знань, умінь та інших компетентностей у осіб, які здобувають освіту, а також спрямована на формування гармонійно розвиненої особистості $[9,10]$. Відповідно до цього, педагогічні та науково-педагогічні працівники зобов'язані сприяти розвитку здібностей здобувачів освіти, формуванню навичок здорового способу життя, дбати про їхнє фізичне і психічне здоров'я [10].

Це може бути реалізовано через раціональну організацію процесу фізичного виховання в закладах фахової передвищої освіти, а також в умовах дозвіллєвої діяльності студентської молоді з урахуванням потребово-мотиваційних цінностей учасників освітнього процесу [10]. Процес фізичного виховання студентської молоді обумовлений його тісним зв'язком із покращенням фізичної підготовленості, зміцненням здоров'я та фізичним удосконаленням майбутніх високоосвічених фахівців [16].

Фізичне виховання є важливою складовою системи освіти майбутніх фахівців, яке відіграє важливу роль у збереженні й зміцненні здоров'я студентської молоді, підвищенні фізичної працездатності, збільшенні тривалості життя, формуванні професійно-важливих якостей особистості. Проте підходи до оцінювання фізичної підготовленості студентів фахової передвищої освіти не мають певної диференціації відповідно до сучасних вимог.

Роботу виконано згідно з планом наукової роботи НУФВСУ на 2016-2020 рр. відповідно до теми кафедри теорії і методики фізичного виховання 3.1 «еоретико-методологічні основи вдосконалення програмно-нормативних засад фізичної підготовки дітей, підлітків і молоді» (номер держреєстрації 0116U001626).

Мета дослідження - визначити сучасні підходи до оцінювання рівня фізичної підготовленості як обов'язкової складової освітнього процесу студентської молоді закладів фахової передвищої освіти.

Методи дослідження: теоретичний аналіз і узагальнення даних літературних джерел, передового педагогічного та наукового досвіду.

Результати дослідження та іх обговорення. У зв'язку з незадовільним станом системи освіти в Україні з 2000 р. розпочато процес модернізації їі змісту в цілому. Відповідно до законодавчих та нормативно-правових актів у закладах фахової передвищої освіти викладання предмета «Фізична культура» повинне регламентуватись навчальною програмою для вищих навчальних закладів I-II рівнів акредитації та наказом Міністерства освіти і науки України від 01.06.2018 р. № 570 «Про затвердження типової освітньої програми профільної середньої освіти закладів освіти, що здійснюють підготовку молодших спеціалістів на основі базової загальної середньої освіти» [18]. Відповідно до цього, в процесі підготовки здобувачів освітньо-кваліфікаційного рівня молодший спеціаліст у типовій освітній програмі визначено загальний обсяг і структуру навчального навантаження і передбачено у переліку предметів профільної середньої освіти вивчення предмета «Фізична культура» як базового в обсязі не менше 210 год на рік для всіх спеціальностей, та 420 год на рік як профільного предмета для спеціальностей, які готують фахівців для сфери фізичної культури і спорту.

Ефективність організації процесу фізичного виховання нерозривно пов'язана 3 діагностикою рівня фізичного стану, фізичної підготовленості та рівня здоров'я [11].

Тестовий контроль фізичного розвитку й фізичної підготовленості студентів - методологічна основа управління процесом фізичного виховання. Своєчасна і якісна діагностика поточного рівня фізичної підготовленості має важливе прикладне значення для оцінювання ефективності впливу фізичних навантажень на організм у процесі навчання. Методично правильно побудований процес фізичного виховання молоді з використанням адекватних форм організації та методів контролю сприятиме приросту результатів фізичної підготовленості [15]. Тому виникає необхідність не лише в перегляді традиційних підходів до процесу фізичного виховання, а й виникають нові вимоги та висуваються критерії до системи оцінювання рівня фізичної підготовленості студентської молоді.

Відповідно до постанови Кабінету Міністрів України від 09 грудня 2015 року № 1045 «Про затвердження Порядку проведення щорічного оцінювання фізичної підготовленості населення України» [7], регламентується оцінювання фізичної підготовленості учнівської молоді з метою визначення та підвищення іï рівня серед населення України, що передбачає виконання особами різної статі та віку комплексу тестів і нормативів для визначення рівня їхньої фізичної підготовленості, а також наказ Міністерства молоді та спорту України № 4607 від 04.10.2018 «Про затвердження тестів і 
нормативів для осіб, щорічне оцінювання фізичної підготовленості яких проводиться на добровільних засадах, Інструкції про організацію його проведення та форми Звіту про результати його проведення» [6], відповідно до якого з'являється можливість визначити рівень розвитку фізичних якостей та оцінити різнобічність (гармонійність) розвитку основних фізичних якостей відповідно до статевих і вікових особливостей розвитку людини.

Контрольні нормативи, передбачені в процесі фізичного виховання різних вікових груп, на думку ряду фахівців [11-13], недостатньо обгрунтовані. Вони не відповідають віковим, руховим та функціональним особливостям дітей та молоді. Чинною програмою з фізичної культури не передбачено диференціацію в оцінюванні фізичної підготовленості учнівської молоді залежно від її морфологічних показників, рівня фізичного здоров'я.

Сучасні умови життєдіяльності студентської молоді, а також уявлення про норму безперервно і швидко змінюються. Вибір базових критеріїв оцінювання рухової підготовленості багато у чому пов'язаний із великою різноманітністю контрольних тестів, використовуваних фахівцями галузі фізичної культури для контролю рівня розвитку окремих рухових здібностей [8, 11].

На думку ряду фахівців [13, 17], одним із найважливіших завдань сучасної освіти є перехід до індивідуалізації та диференціації навчання. На сьогодні існує брак інформації про те, які результати рухових тестів повинні бути у студентів із «безпечним» рівнем фізичного здоров'я, що гарантує повну відсутність і сам ризик виникнення захворювань.

За даним В. М. Сергієнко, контроль рівня фізичної підготовленості достатньою мірою характеризує фізичний стан студентів, а залежність між рівнем фізичної підготовленості та здоров'я дає можливість використовувати дані про їхній стан як діагностично-прогностичний показник, який підтверджує необхідність контролю розвитку окремих рухових здібностей (силових, швидкісних, координаційних витривалості й гнучкості) та здоров'я, в процесі фізичного виховання закладів фахової передвищої освіти [21].

За даними ряду вчених, критерієм нормативу розвитку рухових якостей учнівської молоді повинна бути не порівняльна норма, заснована на середніх стандартах, а належна, заснована на відповідності її високому рівню здоров'я, професійної і побутової працездатності [2, 12].

Стану здоров'я студентської молоді присвячені дослідження багатьох дослідників, зокрема Ю. О. Доценка, Л. П. Долженко, С. В. Трачука, Л. І. Кузнецова, Н. В. Москаленко [4, 5, 14, 17], які акцентують увагу на проведенні занять із фізичного виховання з урахуванням рівня здоров’я, фізичної підготовленості, показників фізичної працездатності та психофізичної готовності до майбутньої професійної діяльності.
Протягом багатьох років спостерігається значне погіршення здоров'я й зниження рівня фізичної підготовленості учнівської та, як наслідок, студентської молоді. Лонгітюдні дослідження фізичної підготовленості абітурієнтів та студентської молоді засвідчили, що понад 50 \% із них мають незадовільну фізичну підготовленість, значні фізичні вади, захворювання [10].

Формування ціннісного ставлення юнацтва, дітей та молоді до власного здоров'я, покращення фізичного розвитку та фізичної підготовленості з урахуванням вимог майбутньої професійної діяльності внесено до першочергових заходів реалізації Національної стратегії з оздоровчої рухової активності в Україні на період до 2025 року «Рухова активність - здоровий спосіб життя - здорова нація» на 2018 р. [19]. При цьому слід враховувати, що у 2019 р. було прийнято Закон України «Про фахову передвищу освіту», який визначає порядок, умови, форми та особливості здобуття фахової передвищої освіти [10].

Одним із пріоритетних завдань фізичного виховання та масового спорту у закладах фахової передвищої освіти є досягнення належного рівня здоров'я і високого рівня фізичної підготовленості, працездатності й інших компонентів фізичного стану як складових навчально-виховного процесу 3 фізичного виховання [12].

Для вирішення відповідних завдань, які стоять перед підготовкою майбутніх фахівців, слід розробляти диференційований підхід до оцінювання фізичної підготовленості з методично правильною побудовою процесу фізичного виховання молоді 3 використанням адекватних форм організації та методів контролю. При цьому потрібно враховувати, що система оцінювання має бути гуманною, неприпустимі дискримінація особистості, обмеження іiі гідності у зв'язку з різним рівнем фізичних можливостей. Серед напрямів діяльності викладача повинні бути враховані не тільки результати тестів фізичної підготовленості, а й ставлення студентів до цього виду діяльності, рівень сформованої потреби та мотивації до цих занять [15].

У роботі Т. I. Дейніченко диференційований підхід розглядається як компонент управління навчанням, у якому під час розподілу учнів на групи пропонується враховувати не лише їхній рівень фізичного розвитку, а й психологічні особливості й функціональні можливості організму [3].

На думку I. Р. Боднар зі співавт., тестування фізичної підготовленості за нормативами без урахування показників фізичного розвитку не сприяє мотивуванню учнівської молоді до подальшого фізичного самовдосконалення. Воно призводять до виникнення високої ситуативної тривожності несприятливого психоемоційного стану. Це дозволило авторам обгрунтувати та розробити диференційовані нормативи оцінювання рівня фізичної підготовленості учнівської молоді з урахуванням показників фізичного розвитку. Відповідно до цих 
даних було спроектовано орієнтовні навчальні нормативи з урахуванням різних за рівнем показників фізичного розвитку як критерію диференціації [1].

За даними М. Стефанишина, визначення критеріїв диференційованого оцінювання фізичної підготовленості з урахуванням антропометричних ознак фізичного розвитку під час занять фізичною культурою дає змогу коректно та оперативно встановити рівень фізичної підготовленості [22].

За результатами досліджень Г. В. Охромій, С. В. Ноздріна, Н. Ю. Макарової, виявлено, що 40,5 \% студентів на початку навчального року вважають програмні фізичні навантаження надмірними і лише 1,2 \% - недостатніми, а 85-90 \% студентів не можуть виконати контрольні нормативи через низький рівень фізичної підготовленості [20].

Застосовувані в навчальному процесі контрольні нормативи неприйнятні для студентів, у яких біологічний вік не відповідає паспортному. Невисокий потенціал індивідуального здоров'я, наявність шкідливих звичок і патологічних хворобливих станів свідчать про необхідність змін нормативів у програмі для 3ВО, а також застосування диференційованого підходу до кожної групи студентів з урахуванням їхнього фізичного розвитку, психофізіологічного стану та рівня здоров'я [20].

У сучасній практиці фізичного виховання i спортивного тренування усвідомлена необхідність використання різних видів, методів і засобів контролю в їх поєднанні. Під комплексним контролем розуміють сукупність тестових методик та організаційних заходів для отримання повної інформації про рівень фізичного розвитку, стан здоров'я, спортивну підготовленість особистості [21]. Це викликає необхідність диференційованого підходу до організації процесу фізичного виховання молоді, основною метою якого є оптимізація освітнього процесу та обгрунтування методики занять для розвитку основних і професійно необхідних фізичних якостей.

Аналіз науково-методичної літератури, присвяченої підходам до оцінювання рівня фізичної підготовленості студентської молоді закладів фахової передвищої освіти, виявив ряд проблем, які з метою вдосконалення процесу фізичного виховання потребують нагального вирішення.

Питання диференціації підходів до оцінювання рівня фізичної підготовленості студентської моло- ді за останні роки не втратили своєї актуальності, що підтверджують роботи ряду вчених [1, 2, 16, 21, 22].

Враховуючи схожість підходів до організації процесу фізичного виховання учнів старшого шкільного віку та студентів, які навчаються в закладах фахової передвищої освіти, має сенс розглянути питання про модернізацію програми фізичного виховання, що буде потребувати й зміни самої оцінки фізичної підготовленості зазначеного контингенту.

Врахування показників рівня фізичного здоров'я в процесі занять 3 фізичного виховання та під час оцінювання рівня фізичної підготовленості сприятиме підвищенню ефективності процесу фізичного виховання.

Висновки. У сучасній науковій літературі досить широко розглянуто питання диференційованого підходу до організації процесу фізичного виховання різних вікових груп, проте незначна кількість робіт в цьому контексті розглядає підходи до оцінювання рівня фізичної підготовленості студентів закладів фахової передвищої освіти, що, в свою чергу, повинно сприяти підвищенню рівня розумової та фізичної працездатності, фізичного здоров'я та мотивації до занять фізичною культурою і спортом.

Серед багатьох причин, що не дозволяють прийняти адекватні рішення про вдосконалення процесу фізичного виховання студентської молоді закладів фахової передвищої освіти, є відсутність в освітніх установах практики врахування рівня фізичного здоров'я, антропометричних даних, інтересів, схильності до певного виду рухової діяльності та спорту. Тому у вирішенні проблеми модернізації процесу фізичного виховання студентської молоді закладів фахової передвищої освіти необхідно йти шляхом подальшої диференціації підходів до оцінювання їхнього рівня фізичної підготовленості з урахуванням майбутньої професійної діяльності.

Перспективи подальших досліджень полягають у вивченні диференційованого підходу до критеріїв оцінювання рівня фізичної підготовленості студентської молоді закладів фахової передвищої світи з урахуванням стану фізичного здоров’я.

Конфлікт інтересів. Автори заявляють, що відсутній будь-який конфлікт інтересів.

\section{Література}

1. Боднар IP, Стефранишин MB, Петришин ЮВ. Оцінювання рівня фрізичної підготовленості учнів старших класів з урахуванням показників фрізичного розвитку. Педагогіка, психологія та медико-біологічні проблеми фрізичного виховання і спорту. 2016;6:9-17. doi:10.15561/18189172.2016.0602.

2. Давиденко ОВ, Семененко ВП, Трачук СВ. Основи програмування фізкультурно-оздоровчих занять з дитячим контингентом: навч. посіб. Київ: ТОВ Видавничий дім АртЕк; 2019. 248 с.

3. Дейніченко TI. Диференціація навчання в процесі групової форми його організації (на прикладі предметів природничо-математичного циклу) [автореферат]. Харків: Харків. нац. пед. ун-т ім. Г. С. Сковороди; 2006.21 с. 
4. Долженко ЛП. Фізична підготовленість і функціональні особливості студентів із різним рівнем фрізичного здоров'я [авторефрерат]. Київ: НУФВСУ; 2007. 22 с.

5. Доценко ЮО. Оцінка психофрізичної готовності студентів ВНЗ гірничодобувного профрілю до трудової діяльності [автореферат]. Київ; 2015. 23 с.

6. Закон України «Про державні тести і нормативи оцінки фрізичної підготовленості населення України» [Internet]. 2018.[ цитовано 2019 грудень 9]. № 1207/32659. Доступно на: https://zakon.rada.gov.ua/laws/show/ z0195-17/print

7. Закон України «Про затвердження Порядку проведення щорічного оцінювання фрізичної підготовленості населення України» [Internet]. 2015. [цитовано 2019 грудень 9]. № 1045. Доступно на: https://zakon.rada.gov. ua/laws/show/1045-2015-\%D0\%BF/print

8. Закон України «Про затвердження тестів і нормативів для осіб, щорічне оцінювання фрізичної підготовленості яких проводиться на добровільних засадах, Інструкції про організацію його проведення та фрорми Звіту про результати його проведення» [Internet]. 2018. [цитовано 2019 грудень 9]. № 1207/32659. Доступно на: https://zakon.rada.gov.ua/laws/show/z1207-18/print

9. Закон України «Про освіту» [Internet]. 2017. [цитовано 2019 грудень 9]. № 2745-VIII Доступно на: https:// zakon.rada.gov.ua/laws/show/2145-19/print

10. Закон України «Про фахову передвищу освіту» [Internet]. 2019. [цитовано 2019 грудень 9]. № 2745-VIII. Доступно на: https://zakon.rada.gov.ua/laws/show/2745-19

11. Круцевич ТЮ, Воробйов ВІ, Безверхня ГВ. Контроль у фрізичному вихованні дітей, підлітків і молоді. Київ: Олімп. л-ра; 2011. 224 с.

12. Круцевич ТЮ, Трачук СВ, Кузнецова ЛІ. Фізична підготовленість юнаків коледжів різних спеціальностей. Вісник Чернігів. нац. пед. університету. Серія: Педагогічні науки. Фізичне виховання та спорт. $2016 ; 136$. 115-119.

13. Круцевич ТЮ, редактор. Теорія і методика фрізичного виховання: підручник для спец. ВНЗ фрізичного виховання і спорту. Київ: Олімпійська літ.; 2017. Т. 2, С. 392.

14. Кузнецова Л, Трачук С, Покас Б. Оцінка добової рухової активності студентів коледжу методом метаболічного еквіваленту. Теорія і методика фріз. виховання і спорту. 2018; 4. 66-69.

15. Кузнєцова ОТ. Динаміка рівнів фрізичної підготовленості студентів-першокурсників технічних ВН3. Молода спортивна наука України: зб. наук. пр. 2014; 18. 69-74.

16. Маленюк Т. Оцінка фрізичної підготовленості студентів (18-19 років) фракультету фізичного виховання. Фізичне виховання, спорт і культура здоров'я у сучасному суспільстві: зб. наук. праць. 2012; 4. 87-90.

17. Москаленко НВ, Сычова ТВ. Инновационные технологии в физическом воспитании студентов. Инновационные технологи в физическом воспитании, спорте и физической реабилитации: I Междунар. науч.практ. конф; 2015; Орехово-Зуево. МГОГИ; 2015. Т 2; С. 59-64.

18. Наказ МОН України «Про затвердження типової освітньої програми профрільної середньої освіти закладів освіти, що здійснюють підготовку молодших спеціалістів на основі базової загальної середньої освіти» [Internet]. 2018. [цитовано 2019 грудень 9]. № 570. Доступно на: https://mon.gov.ua/storage/app/uploads/ public/5b1/2b5/d5d/5b12b5d5d1479804162014.pdf

19. Національна стратегія з оздоровчої рухової активності в Україні на період до 2025 року «Рухова активність - здоровий спосіб життя - здорова нація». - Режим доступу: http://zakon2.rada.gov.ua/laws/ show/42/2016

20. Охромій ГВ, Ноздрін СВ, Макарова НЮ. Сучасні інноваційні методи індивідуальних фізичних навантажень для студентів. Вісник соціальної гігієни та організації охорони здоров'я України. 2015; 2: $24-27$.

21. Сергієнко ВМ. Система контролю рухових здібностей студентської молоді: теорія і методологія фізичного виховання [монографрія]. Суми: Сумський державний університет. 2015; 392 с.

22. Стефранишин МВ. Диференціація оцінювання фрізичної підготовленості школярів 10-11 класів [дисертація]. Львів; 2017. 219 с.

\section{Literature}

1. Bodnar IR, Stefanyshyn MV, Petryshyn IV. Assessing physical fitness level of senior school children with account for physical development indices. Pedahohika, psykholohiia ta medyko-biolohichni problem fizychnoho vykhovannia i sportu. 2016;6:9-17. doi:10.15561/18189172.2016.0602.

2. Davydenko OV, Semenenko VP, Trachuk SV. Fundamentals of programming physical education and health classes with children: teaching guide. Kyiv: TOV Vydavnychyi dim ArtEk; 2019. 248 p.

3. Deynichenko TI. Differentiation of learning in the process of group form of its organization (on the example of natural sciences and mathematics) [author's abstract]. Kharkiv: Natsionalnyi pedahohichnyi universytet imeni H.Skovorody; 2006. 21 p.

4. Dolzhenko LP. Physical fitness and functional features of students with different physical health level [author's abstract]. Kyiv: NUPESU; 2007. 22 p.

5. Dotsenko IO. Assessment of psychophysical fitness of mining students for labor activity [author's abstract]. Kyiv; 2015. 23 p. 
6. Law of Ukraine «On state tests and standards for assessing the physical fitness of the population of Ukraine» [Internet]. 2018. [cited 2019 December 9]. № 1207/32659. Available at: https://zakon.rada.gov.ua/laws/show/z0195$17 /$ print

7. Law of Ukraine «On approval of the Procedure for conducting annual assessment of physical fitness of the population of Ukraine» [Internet]. 2015. [cited 2019 December 9]. № 1045. Available at: https://zakon.rada.gov.ua/ laws/show/1045-2015-\%D0\%BF/print

8. Law of Ukraine «On approval of tests and standards for persons whose annual assessment of physical fitness is carried out on a voluntary basis, Instructions on the organization of its conduct and forms of the Report on the results of its conduct» [Internet]. 2018. [cited 2019 December 9]. № 1207/32659. Available at: https://zakon.rada. gov.ua/laws/show/z1207-18/print

9. Law of Ukraine «On Education» [Internet]. 2017. [cited 2019 December 9]. № 2745-VIII Available at: https:// zakon.rada.gov.ua/laws/show/2145-19/print

10. Law ofUkraine «On Professional HigherEducation» [Internet]. 2019. [cited 2019 December9]. №2745-VIII.Available at: https://zakon.rada.gov.ua/laws/show/2745-19

11. Krutsevych TI, Vorobiov VI, Bezverkhnia HV. Control in physical education of children, adolescents and youth. Kyiv: Olimpiyska literatura; 2011. 224 p.

12. Krutsevych TI, Trachuk SV, Kuznetsova LI. Physical fitness of young people from colleges of different specialties. Visnyk Chernihivskoho natsionalnoho pedahohichnoho universytetu. 2016; 136. 115-119.

13. Krutsevych TI. Theory and methods of physical education: a textbook for special. University of Physical Education and Sports. Kyiv: Olimpiyska literatura; 2017. T. 2, C. 392.

14. Kuznetsova L, Trachuk S, Pokas B. Evaluation of daily motor activity of college students by the method of metabolic equivalent. Teoriia i metodyka fizvykhovannia i sportu. 2018; 4. 66-69.

15. Kuznetsova OT. Dynamics of levels of physical fitness of first-year students of technical universities. Moloda sportyvna nauka Ukrainy. 2014; 18. 69-74.

16. Maleniuk T. Assessment of physical fitness of students (18-19 years) of the Faculty of Physical Education. Fizvykhovannia, sport i kultura zdorovia u suchasnomu suspilstvi. 2012; 4. 87-90.

17. Moskalenko NV, Sychova TV. Innovation technologies in physical education of students. Innovation technologists in physical education, sports and physical rehabilitation: I Mezhdunarodnaya nauchno-prakt. Konferentsiya; 2015; Orekhovo-Zuyevo. MGOGI; 2015. Vol 2; P. 59-64.

18. Order of the Ministry of Education and Science of Ukraine «On approval of a standard educational program of specialized secondary education of educational institutions that train junior specialists on the basis of basic general secondary education» [Internet]. 2018. [cited 2019 December 9]. № 570. Available at: https://mon.gov.ua/storage/ app/uploads/public/5b1/2b5/d5d/5b12b5d5d1479804162014.pdf

19. National Strategy for Physical Activity in Ukraine for the period up to 2025 «Physical activity - a healthy lifestyle - a healthy nation». - Access mode: http://zakon2.rada.gov.ua/laws/ show/42/2016

20. Okhromii HV, Nozdrin SV, Makarova NI. Modern innovative methods of individual physical activity for students. Visnyk sotsialnoi hihiieny ta orhanizatsii okhorony zdorovia Ukrainy. 2015; 2: 24-27.

21. Serhiienko VM. The system of control of motor abilities of student youth: theory and methodology of physical education [monograph]. Sumy: Sumskyi derzhavnyi universytet. 2015; 392 p.

22. Stefanyshyn MV. Differentiation of assessment of physical fitness of schoolchildren of 10-11 classes [dissertation]. Lviv; 2017. 219 p.

\section{Інформація про авторів}

Семененко В'ячеслав Петрович, https://orcid.org/0000-0001-5774-0868 semenenko_v@bigmir.net,

Національний університет фізичного виховання і спорту України, 03150, Київ, вул. Фізкультури, 1.

\section{Information about the authors}

Semenenko Viacheslav,

https://orcid.org/0000-0001-5774-0868 semenenko_v@bigmir.net,

National University of Ukraine on Physical Education and Sport, 03150, Kyiv, Fizkul'tury str., 1. 